Article

\title{
Household Barriers to Climate Change Action: Perspectives from Nuevo Leon, Mexico
}

\author{
D. Liliana González-Hernández ${ }^{1, *(\mathbb{D})}$, Erik W. Meijles ${ }^{1,2}$ and Frank Vanclay ${ }^{1}$ (D) \\ 1 Faculty of Spatial Sciences, University of Groningen, PO Box 800, 9700 AV Groningen, The Netherlands \\ 2 Centre for Landscape Studies, University of Groningen, PO Box 716, 9700 AS Groningen, The Netherlands \\ * Correspondence: dulce.liliana.gh@gmail.com
}

Received: 3 July 2019; Accepted: 31 July 2019; Published: 2 August 2019

check for updates

\begin{abstract}
It is necessary to mobilize households so that they make changes to their everyday activities to address climate change. However, in the academic literature, there has been little focus on the perceived barriers to climate change action at the household level. Previous research has also highlighted a need for more studies in Latin America. This study contributes to the literature by filling these gaps. In a face-to-face and online survey administered in Nuevo Leon, Mexico, we asked participants what barriers impede their household from taking action to address climate change. Using thematic analysis, seven main barriers were identified: (i) everyday life; (ii) awareness of climate change; (iii) lack of perceived locus of control; (iv) physical limitations of the dwelling; (v) social, (vi) regulatory; and (vii) economic. Given the significant potential effects of climate change in the Nuevo Leon region, a better understanding of the barriers that prevent households from addressing climate change will inform the development of targeted guidelines and strategies to address changing climate.
\end{abstract}

Keywords: climate change; household level action; community response; adaptation; developing countries; Mexico; barriers to adoption

\section{Introduction}

As the impacts of climate change on human and natural systems are expected to be substantial, a pledge was made in the Paris Climate Agreement to keep global temperature rise below $1.5^{\circ} \mathrm{C}$ above pre-industrial levels [1]. To address this challenge, much research has been devoted to identifying what different stakeholders, including public and private actors, can do to tackle the crisis and reduce the risks and impacts of climate change [1-4]. However, given the complexity of climate change, a society-wide transformation and collaborative efforts across all scales are needed, including small-scale actors like households [5,6]. To achieve the goals set in the Paris Agreement, decisions and actions at the household scale will likely have significant implications for climate change in terms of mitigation [7] and adaptation [8,9].

Households are a fundamental unit of analysis, therefore they have become increasingly visible in climate research $[10,11]$. Households have two main responses to address climate change. The first is through the mitigation of greenhouse gas (GHG) emissions. Household consumption creates significant environmental impact, contributing more than $60 \%$ of worldwide GHG emissions and $50 \%$ to $80 \%$ of total resource use [7]. Therefore, substantial emissions reduction can be achieved by modifying household behavior [12]. The second response is through adaptation. Households are considered to be vulnerable to a changing climate due to their exposure to climatic events [13,14]. However, households have the opportunity to manage the risks and opportunities posed by climate change by carrying out adaptation strategies $[15,16]$. 
A key issue to addressing climate change is the perceived barriers to action [17-19]. Barriers are factors that hinder the planning and implementation of action [17], nonetheless they can often be overcome with support, resources and effort [20]. Research has been carried out on the barriers that prevent households from voluntarily engaging with climate change [2,14,21-23]. Studies suggest that household response to a changing climate is complex, but may be related to various factors, including socio-economic characteristics of the household, access to credit, knowledge and understanding of climate change, comprehension of weather forecast information and long-range weather predictions, risk perceptions, as well as the policy environment [18-26].

While the number of studies on perceptions of climate change continues to grow, studies done in Latin America remain uncommon, with more research being carried out in developed countries [27,28]. This is of particular concern because the effects of climate change will differ between regions, with Latin American countries being identified as particularly vulnerable to its impacts [1]. This paper therefore aims to identify, in a Latin American context, the barriers that prevent households from taking climate change action. To do this, we analyzed the responses to an open-ended question, which were provided by participants in a survey conducted in the state of Nuevo Leon, Mexico, on the topic of climate change perceptions and climate change action.

\section{Barriers to Climate Change Action}

The literature on climate change has identified many barriers that prevent climate change action from being undertaken at individual and higher levels. Several studies highlight a lack of knowledge and awareness among the public as being a main challenge [29,30]. Levels of awareness, knowledge and understanding about climate change are generally low in the wider public and vary within and between countries [31]. While some people are aware of climate change, they often do not have knowledge about its causes, consequences, and possible solutions [29]. Studies that make a conceptual distinction between types of knowledge have shed new light on the role of knowledge in taking action related to climate change. For instance, Shi et al. (2015) reported that climate-relevant knowledge has an influence on people's willingness to take climate change action [30]. Additionally, providing information is essential when people do not know which practices would be effective in a certain situation [32]. One factor that has been proposed as influencing people's understanding of climate change is the media [19]. Although news coverage on climate change is widespread, people frequently tend to distrust the media. In general, people believe that the media exaggerates and sensationalizes climate change stories [19], and they consider that the way the media covers climate change issues is confusing and even misleading [33].

The failure to perceive climate change as a risk has also been associated with reduced uptake of action. Although many people believe that climate change is happening now, they are inclined to believe that the more severe impacts of climate change may not happen until a distant future, or will only affect people in far-away areas [34,35]. This suggests that people underestimate the overall risks of climate change. Another barrier is the low level of priority people give to the topic of climate change. Several studies have shown that the public is more concerned about many other topics, rather than climate change issues [26,36,37]. Many people fail to appreciate that climate change will directly impact them, their households and communities. As a result, they are likely to minimize the extent of the problem, which, in their minds, provides justification for their inaction.

A key aspect of climate change relates to the question of who is responsible for it. Many people deny their own responsibility in contributing to the problem, and may even place blame on other people $[38,39]$. People are often of the opinion that governments should be held accountable for climate change and should take leadership regarding the issue to set regulations to encourage corporations and citizens to modify their behavior [38].

Contrary to the belief that underlining collective responsibility could reduce a person's mitigation and adaptation efforts by diffusing responsibility, Obradovich and Guenther (2016) described how framing the causes of climate change as a collective responsibility, could actually be more effective in 
encouraging pro-climate behavior than stressing personal responsibility [39]. Similarly, Lavallee et al. (2019) reported that participants are more willing to change their behaviors when framing climate change as a collective responsibility as opposed to a personal responsibility [40]. The findings above suggest that framing climate change as personal responsibility may induce negative emotions, such as feelings of personal fault and cognitive dissonance, that subsequently diminish climate change action. Whereas, establishing climate change as a collective responsibility may reduce negative feelings of culpability by assigning responsibility to the entire population.

Studies have also shown that people will not take action if it interferes with their lifestyle or everyday activities $[18,19]$. The greater the required personal sacrifice, the less action will be taken. Moreover, people believe that their individual actions matter little in the grand scheme of things [19]. There is also an assumption that the problem has gone too far and is irreversible, and thus personal action is ineffective $[34,40]$. These fatalistic beliefs reduce action in response to climate change and hinder risk perception [41]. All of this makes it difficult for people to modify their current practices to tackle climate change.

Many households face various economic barriers, which could affect their adoption of clean technology $[18,19]$. The lack of access to financial capital could result in being 'locked-in' to current technology. Many renewable technologies for households, e.g. solar panels, have high upfront costs. Faced with high costs, the public might not take up new technologies, especially in developing countries [42]. The lack of an enabling policy environment, support mechanisms or infrastructure might also prevent people from taking appropriate action. For example, people might consider that, if, for example, there is a lack of public transportation or no convenient recycling centers nearby, they won't use these climate friendly actions [40]. Similarly, the extent to which climate change practices are implemented is likely to be dependent on the capacity of institutions. The effectiveness of practices tends to be constrained by fragmented governance arrangements, inadequate information, and top-down approaches [4].

\section{Methods and Background to the Study Region}

The study was conducted in the state of Nuevo Leon in northeastern Mexico. This region is particularly vulnerable to the impacts of a changing climate. For example, by the end of this century, it is expected that the average annual temperature in Nuevo Leon will rise by 3 to $4{ }^{\circ} \mathrm{C}$ and precipitation will decline by $10 \%$. The region is also exposed to hydro-meteorological phenomena, such as droughts and hurricanes, which are expected to become more severe and more frequent in coming decades [43,44]. All this poses challenges to agriculture and industry, and adds to the strain on the already limited water supplies, which will affect daily household activities [45]. The Nuevo Leon government has been active in developing initiatives to address climate change. However, the research on perceptions of climate change has not been considered in their policies, revealing a lack of a bottom-up approach. Improving the governance of climate change is critical for the state.

Because households need to prepare for a changing climate, our research sought to identify the range of barriers that hinder or prevent action within households in Nuevo Leon. This was done by conducting a face-to-face and online survey in the state. For the purpose of identifying barriers, amongst the 30 or so questions in the questionnaire, an open-ended question was asked: What are the barriers to climate change action in your household? It is the results of the analysis of this question that forms the basis of this paper, while the results of other questions are addressed in another paper [46]. Ethics approval was given for the research by the Faculty of Spatial Sciences at the University of Groningen, and all principles of ethical research, specifically informed consent, were observed [47].

The survey, in online and face-to-face formats, was undertaken between August 2016 and January 2017. The questionnaire and all responses were in Spanish. The online survey was used to ensure maximum response and to minimize sample bias. For this online survey, participants were recruited through popular social media platforms by sending an invitation and link to a Qualtrics survey. In the invitation, there was no mention of climate change in order not to be 'leading', and to minimize 
bias associated with people who have strong feelings one way or the other about climate change. Data collection for the paper questionnaire took place through convenience sampling in the main public squares of several municipalities in the state. The questionnaires were self-completed by the participant without researcher intervention in order to emulate the conditions of the online survey. The online and paper surveys resulted in a total of 622 responses from 12 municipalities in Nuevo Leon. Of these responses, 495 people responded to the open-ended question.

Although individuals answered the surveys, the questions primarily related to the household. In addition to demographic items, and respondent and household characteristics, the survey measured perceptions of climate change, including perceived risk and perceived knowledge, and climate change action. Through an open-ended question, respondents were asked what, according to them, were the main barriers to climate change action in their household [48]. The responses to the open-ended question were analyzed through thematic analysis, which is a qualitative approach that uses codes to identify, analyze, and report patterns within textual data [43]. In an Excel spreadsheet, a system of emergent coding was used, with up to three codes (which are a bit like keywords) being applied summarizing each respondent's answer to the open-ended question. In a second round, related codes were grouped together, thus creating themes and subthemes. To develop the lead author's skill and confidence in the coding process, the initial 100 responses were coded individually by three people (two of the authors and a colleague), and then discussed, with a codebook being created. The remaining 395 responses were coded only by the lead researcher following the codebook. All extracts used in this paper were translated into English from Spanish by the lead author.

\section{Overview of Respondents}

A total of 622 surveys were received, of which 495 people responded to the open-ended question. The representativeness of this sample $(n=495)$ can be compared to the state average using data from the National Institute of Statistics and Geography (INEGI) (see Table 1). The respondents to the question of interest were $56 \%$ female. The age of respondents ranged from 18 to 74 years old, with a median age of 30 , which is comparable to a state median of 29 . The majority $(90 \%)$ had at least completed high school, and half had completed a bachelor's degree or higher. This was an over-representation of more highly educated people, as might be expected for a survey of this kind. Analyses comparing higher educated to lesser educated respondents showed that actually there was little difference between these two sub-samples. Household income ranged widely, with $29 \%$ earning less than MXN \$10,000 (about USD 500) and 3\% earning more than MXN \$80,000 (USD 4000) monthly. The aggregation of the National Institute of Statistics and Geography (INEGI) data and the classed nature of how we asked about income makes it difficult to compare, however, it can be roughly suggested that the income distribution of the sample is not substantially different to the state data. As with the state data, the vast majority of respondents' households were located in urban settings and had a median household size of four people. The great proportion of households had at least one working adult, while $4 \%$ only comprised people who were unemployed or economically inactive due to retirement or study.

Table 1. Comparison of sample with the Nuevo Leon population.

\begin{tabular}{cccc}
\hline Characteristic & Classes & $\begin{array}{c}\text { Respondent Sample (\%) } \\
(\mathbf{n}=\mathbf{4 9 5 )}\end{array}$ & $\begin{array}{c}\text { Nuevo Leon Population } \\
\mathbf{( \% )}\end{array}$ \\
\hline Household Profile & & & \\
\hline \multirow{2}{*}{ household setting } & urban & 91 & 95 \\
& rural & 6 & 5 \\
\hline
\end{tabular}


Table 1. Cont.

\begin{tabular}{|c|c|c|c|}
\hline Characteristic & Classes & $\begin{array}{l}\text { Respondent Sample }(\%) \\
\qquad(\mathrm{n}=495)\end{array}$ & $\begin{array}{c}\text { Nuevo Leon Population } \\
(\%)\end{array}$ \\
\hline \multirow{5}{*}{$\begin{array}{l}\text { household income } \\
\text { (MXN per month) }\end{array}$} & rather not say & 13 & \multirow{5}{*}{$\begin{array}{l}\$ 11,949 \mathrm{MXN} \\
\text { (average) }\end{array}$} \\
\hline & less than $\$ 10,000$ & 29 & \\
\hline & $\$ 10,000-\$ 30,000$ & 35 & \\
\hline & $\$ 30,000-\$ 80,000$ & 21 & \\
\hline & more than $\$ 80,000$ & 3 & \\
\hline household size & median & 4 & 3.7 \\
\hline \multirow{5}{*}{ employed members } & 1 member & 28 & \multirow[t]{5}{*}{-} \\
\hline & 2 members & 42 & \\
\hline & 3 members & 16 & \\
\hline & 4 or more & 10 & \\
\hline & no members employed & 4 & \\
\hline \multicolumn{4}{|l|}{ Respondent Profile } \\
\hline \multirow{2}{*}{ gender } & male & 44 & 50 \\
\hline & female & 56 & 50 \\
\hline age & median & 30 & 29 \\
\hline \multirow{4}{*}{ education } & less than high school & 10 & 53 \\
\hline & high school & 40 & 23 \\
\hline & bachelor & 36 & 24 \\
\hline & graduate & 14 & - \\
\hline
\end{tabular}

\section{The Barriers to Household Action}

In this section, we explore the barriers to climate change action in households that were expressed by the 495 respondents. Responses to the question of interest varied in length from a few words to around 80 words, with most being a sentence or so. As described in the methods section, the responses were coded into themes and subthemes, with a maximum of three codes being used (for 10 respondents). Over $75 \%$ of the participants gave only one response, whereas around $20 \%$ gave two responses. The thematic analysis revealed seven major themes: (i) everyday life; (ii) awareness of climate change; (iii) lack of perceived locus of control; (iv) physical limitations of the dwelling; (v) social, (vi) regulatory; and (vii) economic. The themes were accompanied by various subthemes (see Table 2) and are detailed below.

\subsection{Everyday Life}

Respondents brought up the 'inconvenience' associated with taking climate change action by referring to their daily routine, habits and comfort, with statements such as, "It's difficult to change our habits" (P475) and "Simply because of existing comforts" (P307). They described how they lived a comfortable life by using technology. For example, they mentioned using air conditioning to cope with the heat, and heaters to warm up their houses during cold spells. Several respondents favored traveling by car over alternative modes of transport because they considered it more convenient for long distances.

Obligations related to work, study and family were evidently setbacks to action as they were mentioned in over 80 responses. Respondents reported working long hours or multiple jobs, hence they 'lacked the time'; and "I do not have enough time to dedicate to these types of practices" (P5). Moreover, there were some respondents who stated that they do not spend much time at home anyway, "Actually, I'm not much at home" (P224). Then again, those who spent time at home detailed that they had to do domestic chores or had to take care of their children or elderly family members, "Sometimes there is no time to do those things. You arrive at your house and you have to do other things like housework" (P320). 
Table 2. Themes and subthemes relating to the perceived barriers to household action.

\begin{tabular}{|c|c|c|c|}
\hline Theme & Subtheme & $\mathbf{n}^{*}$ & Indicative Quotes \\
\hline \multirow{3}{*}{ Everyday Lives } & obligations & 81 & $\begin{array}{l}\text { "At times, various occupations that interfere" (P83) } \\
\text { "The time I have to dedicate to my job" (P107) } \\
\text { "I have other commitments" (P188) }\end{array}$ \\
\hline & lifestyle & 21 & $\begin{array}{l}\text { "Because of existing comforts" (P306) } \\
\text { "It's easier to just use our car" (P378) } \\
\text { "Mainly because of comfort" (P421) }\end{array}$ \\
\hline & relationships & 32 & $\begin{array}{l}\text { "My family does not share my ideas" (P311) } \\
\text { "I try to save water but my dad does spend a lot" (P327) } \\
\text { "The attitude of people who live in my home" (352) }\end{array}$ \\
\hline \multirow{3}{*}{$\begin{array}{l}\text { Awareness of } \\
\text { Climate Change }\end{array}$} & knowledge & 179 & $\begin{array}{l}\text { "There's no information about it" (P146) } \\
\text { "We don't know what to do" (P150) } \\
\text { "Due to a lack of information on the matter" (P203) }\end{array}$ \\
\hline & motivation & 46 & $\begin{array}{c}\text { "Lack of attention" (P116) } \\
\text { “There's no interest from our side" (P314) } \\
\text { "Lack of interest" (P582) }\end{array}$ \\
\hline & urgency & 11 & $\begin{array}{l}\text { "I don't know what extremes we would reach" (P206) } \\
\text { "It's not given its due importance" (P387) } \\
\text { "We don't feel the urgency to do so" (P495) }\end{array}$ \\
\hline \multirow{2}{*}{$\begin{array}{l}\text { Lack of Perceived } \\
\text { Locus of Control }\end{array}$} & self-efficacy & 16 & $\begin{array}{l}\text { "We are not sufficiently prepared" (P192) } \\
\text { "We can't handle that" (P221) } \\
\text { "I can't do much" (P269) }\end{array}$ \\
\hline & lack of control & 20 & $\begin{array}{l}\text { "A few won't make a difference“ (P193) } \\
\text { "Nothing can be done in any case" (P248) } \\
\text { "It's impossible to prevent natural disasters" (P417) }\end{array}$ \\
\hline \multirow{2}{*}{$\begin{array}{l}\text { Physical Limitations } \\
\text { of the Dwelling }\end{array}$} & ownership & 9 & $\begin{array}{l}\text { "My house is rented, so why invest in it" (P343) } \\
\text { "I would do more if I had my own house" (P376) } \\
\text { "We rent our home so it is only temporary" (P430) }\end{array}$ \\
\hline & $\begin{array}{l}\text { housing design } \\
\text { and space }\end{array}$ & 15 & $\begin{array}{l}\text { "Lack of space and construction materials" (P260) } \\
\text { "The land is too small" (P292) } \\
\text { "We are limited by the construction of the property" (P471) }\end{array}$ \\
\hline Social & (no subthemes) & 19 & $\begin{array}{l}\text { "The community does not participate" (P208) } \\
\text { "The lack of culture in society" (P549) } \\
\text { "Lack of community involvement" (P582) }\end{array}$ \\
\hline \multirow{2}{*}{ Regulatory } & $\begin{array}{l}\text { government } \\
\text { management }\end{array}$ & 18 & $\begin{array}{l}\text { "The government doesn't help at all" (P154) } \\
\text { "The government is not organized with waste, etc. " (P428) } \\
\text { "Lack of support from governmental institutions" (588) }\end{array}$ \\
\hline & $\begin{array}{c}\text { lack of } \\
\text { infrastructure }\end{array}$ & 12 & $\begin{array}{l}\text { "Public transport is so deficient" (P190) } \\
\text { "There's no initiatives or access to recycling services" (P409) } \\
\text { "In my city there's no recycling centers" (P418) }\end{array}$ \\
\hline \multirow{2}{*}{ Economic } & financial strain & 81 & $\begin{array}{l}\text { "We have other economic priorities" (P12) } \\
\text { "We don't have the sufficient economic means" (P59) } \\
\text { "Due to our limited economic resources as a family" (P88) }\end{array}$ \\
\hline & affordability & 30 & $\begin{array}{l}\text { "It's expensive to implement solar panels" (P29) } \\
\text { "Solar panels are expensive" (P223) } \\
\text { "Due to the lack of incentives" (P455) }\end{array}$ \\
\hline
\end{tabular}

* Total number of responses was 590 (i.e., average number of comments per person is 1.2).

Respondents also described the relationships between household members (the household structure). Unsupportive members seemed to represent a barrier to climate change action. For example, one woman expressed how she had previously attempted to take action, however had quickly lost motivation without the support of her father: "I try to, I save water but my dad uses a lot" (P327). Even among respondents who lived with housemates, the importance of support to initiate practices was still evident. Respondents provided comments relating to their position in the family, particularly in terms of generational hierarchies. Younger respondents were expected to follow the leadership 
of their parents, which sometimes resulted in disagreements. There was some degree of frustration expressed in a few responses, "Since I am not responsible for our home, my family ignores my suggestions, so my suggestions are not important" (P90) and, "I don't have any say in my house, it belongs to my parents so they're the ones in charge" (P416).

\subsection{Climate Change Awareness}

Over one third of respondents mentioned that they lacked awareness, knowledge or information regarding climate change by stating a 'lack of awareness', 'lack of knowledge', 'lack of information', or similar wordings. In several accounts, we observed that some respondents were aware of how important it was to address climate change. However, they struggled because they were unsure about what measures to take and how to minimize its effects: "Well, I think there are more things or activities [we could do], but we are not informed about that" (P593), and "I really do not know what else can be done inside my home" (P594). Moreover, respondents appear to lack the knowledge or have only a minimal understanding of the impact their current lifestyle has on climate change: "We don't realize what we do is wrong" (P194) and, "We do not know about the effects our household activities have" (P391).

Respondents also emphasized the lack of awareness and knowledge among fellow household members by mentioning it in around 175 responses (35\%). It was made clear that it was hard for information to reach all family members: "We need more information for each member of the family" (P151), and "The family needs to know more about the topic so they can see its importance" (P535). Reasons suggested by respondents for a deficit of knowledge was poor communication on the topic between household members, "We don't have these type of conversations" (P130), and a lack of information from the media, "The media does not provide information about this" (P8), indicating that some people expect that information should come to them, rather than they having to actively seek it.

In a few instances, respondents appeared to be aware of climate change; however, they lacked the motivation and interest to address it, "I think we're apathetic about it" (P207). One man described struggling to take action simply because of the lack of interest on the topic in his household. Closely connected to the lack of interest was the fact that not all respondents believed climate change was an important matter or a threat to them: "Perhaps we do not see such a big problem so close by" (P388), and "Maybe I'm not even around, maybe tomorrow, it is still far away" (P277). A lack of personal experience with climate events could partly influence a sense of urgency, as was suggested by one person (P245) who said words to the effect that: "We need to live that moment [a climate event], because without it we have not felt the consequences of climate change, so we think that we can deal with it if and when it comes". Another person wrote: "We haven't lived through it, [therefore] I don't know what extremes that would be reached" (P206).

\subsection{Lack of Perceived Locus of Control and Self-Efficacy}

There was a belief among respondents that they do not have the necessary skills to perform complex tasks to address climate change, or would struggle to do so: "We can't handle that" (P221). At the same time, they felt that their behavior would not make a difference: "I believe our actions won't generate important effects" (P192). In a few cases, there was a feeling of being overwhelmed, particularly for those who felt that climate change and its associated effects were beyond their control: "There's nothing we can do. It's impossible to prevent natural disasters" (P417). Several respondents pointed out that they would just have to 'get through' events such as natural disasters since they believed "nothing can be done in any case" (P248).

\subsection{Physical Limitations of the Dwelling}

Respondents living in a rented house revealed feeling limited responsibility for what they can and cannot modify. In many ways, they felt they have little to gain by making investment through renovation: "I rent my house, so why would I invest in it?" (P343). One man reported that if he was to 
own a home, he would surely prepare it for natural disasters, nonetheless he felt he could not do so in his current living situation. Homeowners also reported limitations relating to housing design, and the physical construction of their dwelling. A small number of respondents cited the lack of space in their property as a being a barrier to planting trees or having a garden: "The land is too small, there is no space to plant trees" (P292).

\subsection{Social}

Respondents addressed social influences outside of their households, including relationships with neighbors and society, as affecting their interest in taking climate change action. There was a sense of discontent and frustration when other people in their community did not take measures to prevent climate change, when the respondent felt they could easily do so. Some described negative experiences regarding the wastefulness of society. One woman recounted her experience: "The lack of cultura [manners, proper behavior] in society, we do not throw garbage in the streets, but there are many people who do. We try to save water, but our neighbor hoses down the sidewalk" (P549).

\subsection{Regulatory}

Respondents felt that government authorities did not have any political will to tackle climate change. One group of respondents believed that the government should not hesitate to address climate change and could do much more on the matter, for example by increasing taxes on industry emissions, regulating corporations, and through the creation of climate legislation. However, another group of respondents described that, even if such policies existed, the government would not be able to enforce them. They were doubtful that the authorities of Nuevo Leon would ever do anything outside their own personal interests. Moreover, they felt that the authorities abused their power at the cost of the state's population, which led to feelings of mistrust and skepticism. These respondents demonstrated a considerable degree of resentment towards public servants, "The government is full of crooks who don't help at all (P9)".

Respondents described how the lack of initiatives related to climate change affected them in several ways. One of the most frequent areas discussed was the lack of recycling programs. In general, respondents explained that they sorted (or had the intention to sort) waste at home, but they felt that their efforts were lost as the waste would end up as mixed waste anyway: "At home the garbage is separated, but in the collection truck it all gets mixed up" (P656) and, "Even if I classified my trash ... it would be mixed at the end" (P562). A few comments mentioned that the metropolitan area had neither a bike-friendly culture, nor an efficient public transport system. This was summed up by a respondent who wrote: "I would like to use my bicycle, but the city is not adequate for that and public transport is so inadequate" (P190).

\subsection{Economic}

A lack of economic resources was repeatedly mentioned as a major barrier to implementing climate change action. Respondents reported having low-wage jobs or even multiple jobs. They explained that a large part of their income is consumed by the costs of daily living. Hence, it was impracticable to allocate a larger part of their wages to taking climate change action: "There are other priorities" (P496).

The high cost of products and appliances also complicates taking action. Even those respondents who were willing to take action believed that the technology was expensive and unaffordable: "Implementing new technologies can be expensive" (P64). In particular, the high cost of solar panels was frequently mentioned, through statements such as: "I do not have the financial means needed to implement solar panels" (P59). While some felt that the technology to tackle climate change was expensive, others looked to the fact that there are not many incentives to purchase these products: "We need incentives to finance solar panels" (P451). Comments also emerged about the purchase of eco-friendly products: "Green products are much more expensive" (P440) and "We would need more income to purchase natural items that do not pollute" (P315). 


\section{Discussion and Conclusions}

Our study identified the perceived barriers to household action to address climate change in a Latin American context. Seven types of barriers were identified: (i) everyday life; (ii) awareness of climate change; (iii) lack of perceived locus of control; (iv) physical limitations of the dwelling; (v) social, (vi) regulatory; and (vii) economic. Although these themes have mostly been identified in earlier literature [18-20], we can add further value by thinking more deeply about the barriers. We consider that the barriers can be classified according to whether the source is within or outside the household (see Figure 1). The barriers related to everyday life, awareness of climate change, lack of perceived locus of control, and physical limitations of the dwelling can be considered as being internal, while the social, regulatory, and economic barriers can be considered as being external. Both internal and external barriers have an influence on whether or not households take action to address climate change. However, over $70 \%$ (430 out of 590) of the answers given to our open-ended question, What are the barriers to climate change action in your household?, related to internal barriers. We consider that further research into the internal and external barriers may help clarify how to overcome the barriers, either from inside the household or by stimulating policies from (regional) authorities.

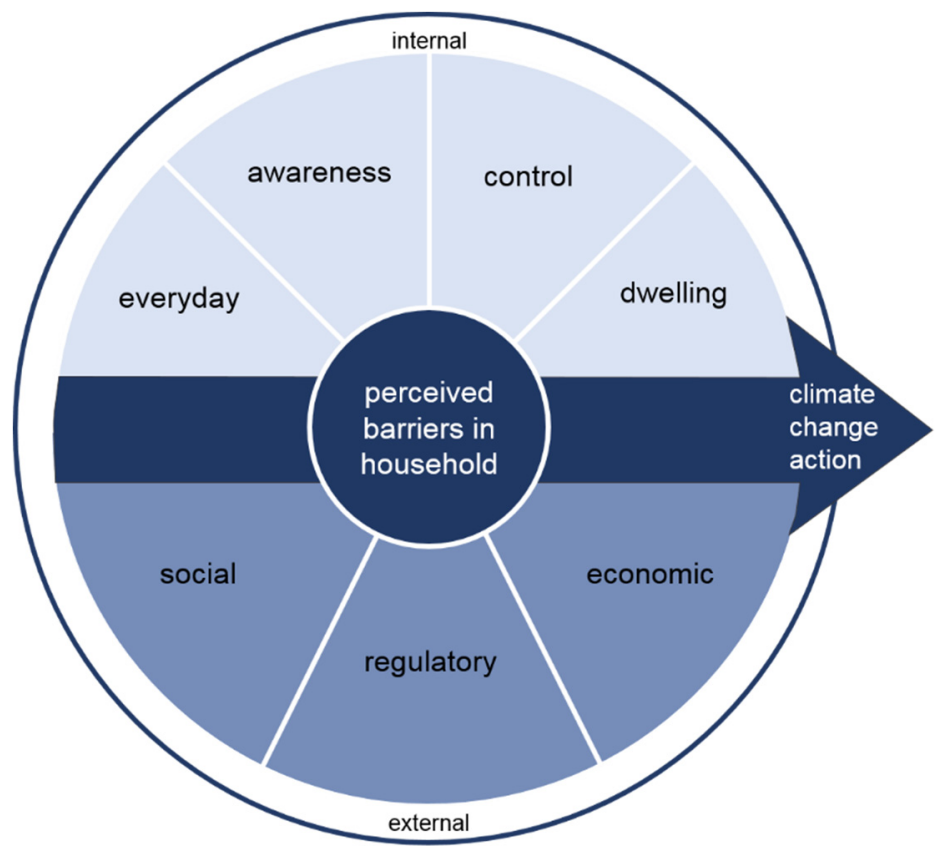

Figure 1. Perceived barriers to climate change from households in Nuevo Leon, Mexico.

It appears that, in many cases, everyday life tends to get in the way of taking action, for example through the inconvenience of changing daily activities. There was a strong sense that respondents felt that addressing climate change requires a considerable time investment, and, with busy schedules and commitments, many people stated that they lacked the time to take the necessary action. Some respondents showed initial interest in taking action, although it was hindered by a lack of support from their fellow household members. In Latin American societies, family cohesiveness takes priority over the self [49], and young people are unlikely to strongly advocate initiatives if they face resistance from older family members. Thus, to promote household climate change action, it is important to create intergenerational interest on the initiatives, so that there will be support within households. A first step would be communicating possible interventions that target all generations to gain a better understanding of climate change, ways to address it, and how to be supportive of other household members.

Respondents highlighted awareness-related barriers in many instances, specifically in terms of a lack of knowledge. Many felt the need to increase their awareness and knowledge of climate change 
and wished for simple and effective strategies about how to tackle climate change in their households. At the same time, there were instances where it seemed that respondents avoided responsibility by pleading a lack of knowledge owing to a lack of information being delivered to them. We argue that, although the public has a responsibility to seek information, the government is also responsible in promoting information. Regardless, the fact that a large group of respondents indicated a lack of awareness as a barrier suggests that providing information about climate change and household level responses is important to address climate change. Therefore, future interventions in Nuevo Leon should include 'tailored information' to facilitate clear messages [34,50], such as communicating advice about how households can manage climate change impacts.

In relation to urgency, respondents mostly had a 'wait and see' approach, and a few framed climate change as only being a distant threat. Although the vast majority of people in the survey regard climate change to be a problem [45], the psychological distance towards the effects of climate change in Nuevo Leon may have contributed to the low risk perception. It was also evident that, for at least a few, a lack of urgency reflected a lack of prior experience with effects attributable to climate change, even though Nuevo Leon had been exposed to a massive drought, followed by torrential rains and flooding only a few years prior to our survey. In the absence of awareness of the potential for serious consequences from climate change, perception of risk remains low. Future communication strategies should focus on reducing this psychological distance in order that people make changes to their behavior from a reactive to a more proactive style. One way to achieve this may be by conveying climate as a collective risk [39] and emphasizing the harsh reality the effects of climate change will likely have on their household, municipality and the state.

Self-efficacy is relevant in understanding how much the respondents believed in their household's ability to address climate change. In their opinion, they are not prepared or skilled enough to take on climate change, and most considered that it might be too difficult to address. Indeed, people are likely to underestimate their potential influence on climate change because of their low level of perceived self-efficacy. In addition, a perceived lack of control over climate change is relevant to understanding why households fail to take action. The responses to our open-ended question made it clear that for a few, climate change is scary, and these kinds of thoughts can lead to perhaps taking the wrong decisions and to potentially negative coping behaviors. Altogether, these findings showed that feelings of low self-efficacy and a lack of control over climate and its effects could compromise respondents' preparedness efforts, thus likely leading to the increased vulnerability of their household to climate change. Future interventions should promote self-efficacy among households, for example by creating projects that foster commitment and enhance capacities among volunteers, as this potentially could give them confidence in performing tasks and making commitments to address climate change.

An issue that was raised by some participants was home ownership. Participants who rented houses resisted taking home improvement actions. Other participants who lived with their parents had similar feelings. They felt that when they would become a homeowner (which is still a common ideal in Mexico), they would then have control over the house and household and would be more likely to implement climate change actions. Our findings also revealed that housing design was a barrier to addressing climate change. Future research should clarify the relationship between ownership, space and design, and how these factors may influence household action towards climate change. Also, research into how policies can positively influence householders to improve homes, especially rented housing, is needed.

In addition to internal barriers, our findings demonstrated how barriers external to the household also played an important role in taking climate change action. For example, regarding societal barriers, some respondent accounts focused on neighborhood and local community connections. Many participants perceived that their neighbors and fellow community members did less than they did. We argue that connections with neighbors and community members had a negative effect on their desire to take action. However, across all responses, it was clear that social connections was not a frequent theme. Nevertheless, we do believe it plays a significant role among those who consider 
it a barrier, maybe more implicit than explicit. As such, building trust and mutual respect among neighbors may assist in fostering collective action, as households will be more prone to act since they are confident that their neighbors will do so. This could be achieved by bringing neighbors together by increasing neighborhood-oriented forms of civic participation. For example, by organizing and promoting meetings through social media, social gatherings or community activities, and improving shared resources, such as green spaces.

Regarding the role of government, two main narratives emerged from the data. First, participants felt that government authorities should do more regarding the climate agenda. Second, the government was perceived as making bad decisions and could not be trusted. Therefore, it is important to restore trust in the government, because a higher level of trust might increase the efficiency and effectiveness of government operations. Stewardship programs that transfer power to citizens have been used to increase civic participation and citizen trust [51], thus a stewardship program potentially could be considered as a central approach to promoting a climate agenda.

Economic resources were the third most mentioned barrier to climate change action, especially regarding household financial strain and the affordability of technology and eco-friendly products. This implies that economic resources were seen as essential to addressing climate change in the household. Thus communication efforts perhaps should focus on approaches to addressing climate change that are not costly. This may help mitigate the feeling that all climate change action needs resources and/or must be supported by financial incentives.

Our research in Nuevo Leon has helped show the importance of studying household barriers to taking climate change action. Households have the opportunity to engage in efforts related to climate change. Understanding the barriers that prevent households from implementing these actions is important in helping households recognize the threat of climate change and taking action to address it. Furthermore, identifying different types of climate change actions and their corresponding barriers can assist in the design of strategies that support the effective application of mitigation and adaptation actions. An increase in research on the experiences of households in relation to the effects of climate change and a closer consideration of the perceived barriers can reveal which types of households could be targeted for initiatives to increase climate change action.

Addressing climate change requires policymakers to acknowledge the role and capacity of households to take climate change action. In the past, this has usually entailed governments contributing to improving the built environment. However, research into addressing the perceived barriers to household action could become a key component of climate change policy.

Author Contributions: Conceptualization, D.L.G.-H. and E.W.M.; methodology, D.L.G.-H. and E.W.M.; formal analysis, D.L.G.-H. and E.W.M.; investigation, D.L.G.-H.; writing-original draft preparation, D.L.G.-H. and E.W.M.; writing-review and editing, D.L.G.-H., E.W.M. and F.V.; supervision, E.W.M. and F.V.

Funding: This research received no external funding.

Acknowledgments: Support for this study was obtained from CONACYT-Gobierno del Estado de Nuevo Leon (Mexican Council for Science and Technology and The Nuevo Leon State Government) through a doctorate scholarship to the first author. We would like to thank Angélica Caiza for her contribution in the data analysis.

Conflicts of Interest: The authors declare no conflict of interest.

\section{References}

1. IPCC. Summary for Policymakers. In Global Warming of $1.5^{\circ} \mathrm{C}$. An IPCC Special Report on the Impacts of Global Warming of $1.5^{\circ} \mathrm{C}$ above Pre-Industrial Levels and Related Global Greenhouse Gas Emission Pathways, in the Context of Strengthening the Global Response to the Threat of Climate Change, Sustainable Development, and Efforts to Eradicate Poverty; Masson-Delmotte, V., Zhai, P., Pörtner, H.-O., Roberts, D., Skea, J., Shukla, P.R., Pirani, A., Moufouma-Okia, W., Péan, C., Pidcock, R., et al., Eds.; World Meteorological Organization: Geneva, Switzerland, 2018. Available online: https://www.ipcc.ch/sr15/chapter/spm/ (accessed on 31 July 2019).

2. Adger, W.N.; Arnell, N.W.; Tompkins, E.L. Successful adaptation to climate change across scales. Glob. Environ. Chang. 2005, 15, 77-86. [CrossRef] 
3. Castán Broto, V.; Bulkeley, H. A survey of urban climate change experiments in 100 cities. Glob. Environ. Chang. 2013, 23, 92-102. [CrossRef] [PubMed]

4. Romero-Lankao, P.; Hughes, S.; Rosas-Huerta, A.; Borquez, R.; Gnatz, D.M. Institutional capacity for climate change responses: An examination of construction and pathways in Mexico City and Santiago. Environ. Plan C Gov. Policy 2013, 31, 785-805. [CrossRef]

5. Clayton, S.; Devine-Wright, P.; Stern, P.C.; Whitmarsh, L.; Carrico, A.; Steg, L.; Swim, J.; Bonnes, M. Psychological research and global climate change. Nat. Clim. Chang. 2015, 5, 640-646. [CrossRef]

6. Batel, S.; Castro, P.; Devine-Wright, P.; Howarth, C. Developing a critical agenda to understand pro-environmental actions: Contributions from social representations and social practices theories. Wiley Interdiscip. Rev. Clim. Chang. 2016, 7, 727-745. [CrossRef]

7. Ivanova, D.; Stadler, K.; Steen-Olsen, K.; Wood, R.; Vita, G.; Tukker, A.; Hertwich, E.G. Environmental impact assessment of household consumption. J. Ind. Ecol. 2016, 20, 526-536. [CrossRef]

8. Kent, N.; Porter, J.; Dessai, S.; Miller, K.; Sibille, R.; Horrocks, L.; Dale, N.; Lonsdale, K.; Ballard, D. PREPARE-The Contribution and Role of Local and Household Level Adaptation in Overall UK Adaptation. Ricardo-AEA 2013.

9. Lo, A.Y. The role of social norms in climate adaptation: Mediating risk perception and flood insurance purchase. Glob. Environ. Chang. 2013, 23, 1249-1257. [CrossRef]

10. Head, L.; Gibson, C.; Gill, N.; Carr, C.; Waitt, G. A meta-ethnography to synthesise household cultural research for climate change response. Local Environ. 2016, 9839, 1-15. [CrossRef]

11. Toole, S.; Klocker, N.; Head, L. Re-thinking climate change adaptation and capacities at the household scale. Clim. Chang. 2016, 135, 203-209. [CrossRef]

12. Dietz, T.; Gardner, G.T.; Gilligan, J.; Stern, P.C.; Vandenbergh, M.P. Household actions can provide a behavioral wedge to rapidly reduce US carbon emissions. Proc. Natl. Acad. Sci. USA 2009, 106, 18452-18456. [CrossRef] [PubMed]

13. Adger, W.N.; Quinn, T.; Lorenzoni, I.; Murphy, C.; Sweeney, J. Changing social contracts in climate-change adaptation. Nat. Clim. Chang. 2013, 3, 330-333. [CrossRef]

14. Bryan, E.; Deressa, T.T.; Gbetibouo, G.A.; Ringler, C. Adaptation to climate change in Ethiopia and South Africa: Options and constraints. Environ. Sci. Policy 2009, 12, 413-426. [CrossRef]

15. Shah, K.U.; Dulal, H.B. Household capacity to adapt to climate change and implications for food security in Trinidad and Tobago. Reg. Environ. Chang. 2015, 15, 1379-1391. [CrossRef]

16. Bryan, E.; Ringler, C.; Okoba, B.; Roncoli, C.; Silvestri, S.; Herrero, M. Adapting agriculture to climate change in Kenya: Household strategies and determinants. J. Environ. Manag. 2013, 114, 26-35. [CrossRef]

17. Eisenack, K.; Moser, S.C.; Hoffmann, E.; Klein, R.J.T.T.; Oberlack, C.; Pechan, A.; Rotter, M.; Termeer, C.J.A.M.A.M.; Eisenack, K.; Termeer, C.J.A.M.A.M.; et al. Explaining and overcoming barriers to climate change adaptation. Nat. Clim. Chang. 2014, 4, 867-872. [CrossRef]

18. Gifford, R. The dragons of inaction: Psychological barriers that limit climate change mitigation and adaptation. Am. Psychol. 2011, 66, 290-302. [CrossRef]

19. Lorenzoni, I.; Nicholson-Cole, S.; Whitmarsh, L. Barriers perceived to engaging with climate change among the UK public and their policy implications. Glob. Environ. Chang. 2007, 17, 445-459. [CrossRef]

20. Moser, S.C.; Ekstrom, J.A. A framework to diagnose barriers to climate change adaptation. Proc. Natl. Acad. Sci. USA 2010, 107, 22026-22031. [CrossRef]

21. Adger, W.N.; Dessai, S.; Goulden, M.; Hulme, M.; Lorenzoni, I.; Nelson, D.R.; Naess, L.O.; Wolf, J.; Wreford, A. Are there social limits to adaptation to climate change? Clim. Chang. 2009, 93, 335-354. [CrossRef]

22. Below, T.B.; Mutabazi, K.D.; Kirschke, D.; Franke, C.; Sieber, S.; Siebert, R.; Tscherning, K. Can farmers' adaptation to climate change be explained by socio-economic household-level variables? Glob. Environ. Change 2012, 22, 223-235. [CrossRef]

23. Eakin, H. Institutional change, climate risk, and rural vulnerability: Cases from Central Mexico. World Dev. 2005, 33, 1923-1938. [CrossRef]

24. Leith, P.; Vanclay, F. Placing science for natural resource management and climate variability: Lessons from narratives of risk, place and identity. Sociol. Rural. 2017, 57, 155-170. [CrossRef]

25. Vogel, C.; O'Brien, K. Who can eat information? Examining the effectiveness of seasonal climate forecasts and regional climate-risk management strategies. Clim. Res. 2006, 33, 111-122. [CrossRef] 
26. Van der Linden, S. Determinants and Measurement of Climate Change Risk Perception, Worry, and Concern. Oxford Res. Encycl. Clim. Sci. 2017, 1,1-53.

27. Capstick, S.; Whitmarsh, L.; Poortinga, W.; Pidgeon, N.; Upham, P. International trends in public perceptions of climate change over the past quarter century. Wiley Interdiscip. Rev. Clim. Chang. 2015, 6, 35-61. [CrossRef]

28. Pardo Martínez, C.I.; Alfonso Piña, W.H.; Moreno, S.F. Prevention, mitigation and adaptation to climate change from perspectives of urban population in an emerging economy. J. Clean. Prod. 2018, 178, 314-324. [CrossRef]

29. Sundblad, E.-L.; Biel, A.; Gärling, T. Knowledge and confidence in knowledge about climate change among experts, journalists, politicians, and laypersons. Environ. Behav. 2009, 41, 281-302. [CrossRef]

30. Shi, J.; Visschers, V.H.M.; Siegrist, M.; Arvai, J. Knowledge as a driver of public perceptions about climate change reassessed. Nat. Clim. Chang. 2016, 6, 759-762. [CrossRef]

31. Lee, T.M.; Markowitz, E.M.; Howe, P.D.; Ko, C.-Y.Y.; Leiserowitz, A.A. Predictors of public climate change awareness and risk perception around the world. Nat. Clim. Chang. 2015, 5, 1014-1020. [CrossRef]

32. Frantz, C.M.; Mayer, F.S. The Emergency of climate change: Why are we failing to take action? Anal. Soc. Issues Public Policy 2009, 9, 205-222. [CrossRef]

33. Ryghaug, M.; Holtan Sørensen, K.; Næss, R.; Sørensen, K.H.; Næss, R. Making sense of global warming: Norwegians appropriating knowledge of anthropogenic climate change. Public Underst. Sci. 2011, 20, 778-795. [CrossRef] [PubMed]

34. Spence, A.; Poortinga, W.; Pidgeon, N. The psychological distance of climate change. Risk Anal. 2012, 32, 957-972. [CrossRef] [PubMed]

35. Leiserowitz, A. Climate change risk perception and policy preferences: The role of affect, imagery, and values. Clim. Chang. 2006, 77, 45-72. [CrossRef]

36. Lorenzoni, I.; Pidgeon, N.F. Public views on climate change: European and USA perspectives. Clim. Chang. 2006, 77, 73-95. [CrossRef]

37. Leiserowitz, A.; Maibach, E.; Rosenthal, S.; Kotcher, J.; Ballew, M.; Goldberg, M.; Gustafson, A. Climate Change in the American Mind: December 2018; Yale Program on Climate Change Communication: New Haven, CT, USA, 2018.

38. Stoddart, M.C.J.; Tindall, D.B.; Greenfield, K.L. "Governments Have the Power"? Interpretations of climate change responsibility and solutions among Canadian environmentalists. Organ. Environ. 2012, 25, 39-58. [CrossRef]

39. Obradovich, N.; Guenther, S.M. Collective responsibility amplifies mitigation behaviors. Clim. Chang. 2016, 137, 307-319. [CrossRef]

40. Lavallee, J.P.; Di Giusto, B.; Yu, T.Y. Collective responsibility framing also leads to mitigation behavior in East Asia: a replication study in Taiwan. Clim. Chang. 2019, 153, 423-438. [CrossRef]

41. Mayer, A.; Smith, E.K. Unstoppable climate change? The influence of fatalistic beliefs about climate change on behavioural change and willingness to pay cross- nationally. Clim. Policy 2019, 4, 511-523. [CrossRef]

42. Waissbein, O.; Glemarec, Y.; Bayraktar, H.; Schmidt, T. Derisking Renewable Energy Investment. A Framework to Support. Policymakers in Selecting Public Instruments to Promote Renewable Energy Investment in Developing Countries; United Nations Development Programme (UNDP): New York, NY, USA, 2015.

43. IPCC. Climate Change 2013: The Physical Science Basis. Contribution of Working Group I to the Fifth Assessment Report of the Intergovernmental Panel on Climate Change; Stocker, T.F., Qin, D., Plattner, G.-K., Tignor, M., Allen, S., Boschung, S., Nauels, A., Xia, Y., Bex, V., Midgley, P.M., Eds.; Cambridge University Press: Cambridge, UK, 2013.

44. Gobierno del Estado de Nuevo León. Programa de Acción ante el Cambio Climático para el Estado de Nuevo León (2010-2015); Gobierno del Estado de Nuevo León: Monterrey, Nuevo León, Mexico, 2010.

45. Sisto, N.P.; Ramírez, A.I.; Aguilar-barajas, I.; Magaña-Rueda, V. Climate threats, water supply vulnerability and the risk of a water crisis in the Monterrey Metropolitan Area (Northeastern Mexico). J. Phys. Chem. Earth 2016, 91, 2-9. [CrossRef]

46. González-Hernández, D.L.; Meijles, E.W.; Vanclay, F. Factors that influence climate change mitigation and adaptation action: A household study in the Nuevo Leon region, Mexico. Climate 2019, 7, 74. [CrossRef]

47. Vanclay, F.; Baines, J.T.; Taylor, C.N. Principles for ethical research involving humans: Ethical professional practice in impact assessment Part, I. Impact Assess. Proj. Apprais. 2013, 31, 243-253. [CrossRef] 
48. Popping, R. Analyzing open-ended questions by means of text analysis procedures. BMS Bull. Sociol. Methodol. Bull. Methodol. Sociol. 2015, 128, 23-39. [CrossRef]

49. Sabogal, F.; Marin, G.; Otero-Sabogal, R. Hispanic familism and acculturation: What changes and what doesn't? Hisp. J. Behav. Sci. 1987, 9, 397-412. [CrossRef]

50. Scannell, L.; Gifford, R. Personally relevant climate change: The role of place attachment and local versus global message framing in engagement. Environ. Behav. 2013, 45, 60-85. [CrossRef]

51. Shandas, V.; Messer, W.B. Fostering green communities through civic engagement: Community-based enviromental stewardship in the Portland area. J. Am. Plan. Assoc. 2008, 74, 408-418. [CrossRef]

(C) 2019 by the authors. Licensee MDPI, Basel, Switzerland. This article is an open access article distributed under the terms and conditions of the Creative Commons Attribution (CC BY) license (http://creativecommons.org/licenses/by/4.0/). 